Katarzyna Doliwa

Uniwersytet w Białymstoku e-mail: kdoliwa@uwb.edu.pl

ORCID: 0000-0001-8583-8379

DOI: 10.15290/mhi.2020.19.01.02

\title{
Spory o pojęcie dzieciństwa i podmiotowość dziecka od średniowiecza do czasów nowożytnych
}

\begin{abstract}
Abstrakt
Artykuł przedstawia kontrowersje wokół pojęcia dzieciństwa i podmiotowości dziecka w epokach minionych - w średniowieczu i w czasach nowożytnych. Jedno $\mathrm{z}$ analizowanych zagadnień dotyczy kwestii istnienia w kulturze średniowiecza rozumienia dziecka jako istoty różnej od dorosłego. Według rozpowszechnionego poglądu, sformułowanego w latach 60. i 70. ubiegłego stulecia przez Philippa Ariésa, dzieciństwo w wiekach średnich nie było dostrzegane, nie uznawano go za odrębny, ważny etap w życiu człowieka, okres którym rządziły szczególne reguły, różne od zasad ważnych w społeczności dorosłych. Dziecko wchodziło bardzo wcześnie w świat dorosłych i przyjmowało wyznaczoną mu w nim rolę. Odkrycie dzieciństwa nastąpiło dopiero w XVI i XVII w., kiedy zaczęto pojmować, że dziecko jest i powinno być podmiotem szczególnego traktowania. Pogląd Ariésa o nieistnieniu w średniowieczu poczucia odrębności dzieciństwa jest przez część mediewistów krytykowany - zarzucają oni francuskiemu badaczowi wady warsztatowe i analizę niereprezentatywnych, zbyt skąpych materiałów źródłowych. Według adwersarzy Ariésa analiza dzieciństwa w średniowieczu nie może być prowadzona na podstawie współczesnej definicji tego terminu, podobnie jak rozpatrywanie relacji „dzieci - dorośli” w wiekach średnich nie może odwoływać się do kategorii współczesnych. Przeciwnicy tezy o nieistnieniu w średniowieczu koncepcji dzieciństwa dowodzą, że epoka ta miała swoją własną jego wizję, tyle że była to wizja zdecydowanie różna od współczesnej. Czasy nowożytne przynoszą nowe podejście do dzieciństwa i podmiotowości dziecka - wiek XVII, obok podejścia, które stawiało dziecko w centrum życia rodzinnego, promuje postawę, kładącą szczególny nacisk na jego rozwój i zaspokojenie potrzeb psychicznych. Wiek XVIII z kolei przynosi
\end{abstract}


„romantyczną" wizję dziecka, kiedy staje się ono - jako nosiciel wyjątkowych cech i istota o niezwykłej wrażliwości - wzorem do naśladowania dla dorosłych. Do ukształtowania się podmiotowego podejścia do dzieci przyczynił się z pewnością rozwój szkolnictwa; ewolucja postawy wobec dziecka w ludzkiej mentalności znajduje swoje najpełniejsze odbicie właśnie w rozwoju edukacji i instytucji szkoły. Dzisiaj pojęcia dzieciństwa i podmiotowości dziecka są przedmiotem złożonych badań interdyscyplinarnych - uczeni z zakresu różnych dziedzin nauki łączą wysiłki, by wypracować jak najpełniejszą, odpowiadającą wyzwaniom współczesności koncepcję dzieciństwa.

\section{Abstract \\ Disputes about the concept of childhood and the child's subjectivity from the Middle Ages to the early modern times}

The article presents the controversy around the concept of childhood and subjectivity of a child in past centuries - in the Middle Ages and the early modern period. One of the analyzed issues concerns the existence in medieval culture of understanding the child as a being different from an adult. According to the widespread view, formulated in the 1960s and 1970s by Philipp Ariés, childhood in the Middle Ages was not noticed, it was not considered a separate, important stage in human life, a period governed by specific rules, different from important principles of the adult community. The child entered the adult world very early and assumed the role assigned to him. The discovery of childhood did not take place until the 16th and 17th centuries, when it began to be recognized that the child was and should be the subject of special treatment. Ariés' view of the non-existence in the Middle Ages of the sense of separateness of childhood is criticized by some medievalists - they accuse the French researcher of technical defects and an analysis of unrepresentative, too scarce source materials. According to the adversaries of Ariés, the analysis of childhood in the Middle Ages cannot be based on the modern definition of this term, just as considering the relationship "children - adults" in the Middle Ages cannot refer to contemporary categories. Opponents of the thesis about the non-existence of the concept of childhood in the Middle Ages argue that this epoch had its own vision of it, but it was a vision definitely different from the present one. The early modern period bring a new approach to childhood and the subjectivity of a child - the seventeenth century, in addition to the approach that the child placed at the center of family life, promotes an attitude that places particular emphasis on the child's development and fulfilment of its mental needs, while the eighteenth century brings a "romantic" vision of the child when it becomes - as a bearer of exceptional qualities and a creature of extraordinary sensitivity - a role model for adults. The development of education has certainly contributed to the formation of a subjective approach to children; the evolution of the attitude towards children in the human mentality finds its fullest reflection in the development of education and school 
institutions. Today, the concepts of childhood and the subjectivity of a child are the subject of complex interdisciplinary research - scientists from various fields of science combine their efforts to develop the most complete concept of childhood, corresponding to the challenges of modern times.

Słowa kluczowe: dzieciństwo, podmiotowość dziecka, P. Ariés, rozwój systemu edukacji

Key words: childhood, child's subjectivity, P. Ariés, development of the education systems

Przypadające na 2020 r. trzydziestolecie obowiązywania Konwencji o Prawach Dziecka ${ }^{1}$ - dokumentu, który przyznał dziecku podmiotowość, wpłynął znacząco na ustawodawstwo wielu państw, a także uregulował i poprawił sytuację dzieci - może być przyczynkiem do refleksji na temat pojęcia dzieciństwa i kształtowania się idei podmiotowości dziecka. Wyróżnienie kategorii dzieciństwa - do której Konwencja wprost się odwołuje - jest warunkiem koniecznym do uznania podmiotowości dziecka. Współcześni filozofowie wśród wyznaczników podmiotowości dostrzegają posiadanie ustalonej tożsamości, samoświadomości i możności sprawczej; dziecko, któremu przyznaje się podmiotowość uznaje się za zdolne do świadomej aktywności, dokonywania - w pewnym zakresie - samodzielnych wyborów i podejmowania decyzji, do wywierania wpływu na otoczenie i na swoje zachowanie, wreszcie zdolne do kształtowania swojego losu ${ }^{2}$. Znamienne, że do szerokiej, filozoficznej definicji ludzkiej podmiotowości chętnie sięgają prawnicy, którzy zajmują się prawem rodzinnym i implementacją przepisów Konwencji do polskiego prawa ${ }^{3}$.

Ukształtowane w XX w. koncepcje dzieciństwa i podmiotowości dziecka ${ }^{4}$ dzieli przepaść od pojęć poprzedzających rewolucyjne zmiany w demografii.

1 Zob. Konwencja o Prawach Dziecka z dnia 20 listopada 1989 r. przyjęta przez Zgromadzenie Ogólne Narodów Zjednoczonych (Dz.U.1991 nr 120, poz. 526).

2 A. Golus, Od przedmiotu do podmiotu. Status dziecka w rodzinie i społeczeństwie, „Studia Edukacyjne" 2018, nr 48, s. 316.

3 Zob. S. L. Stadniczenko, Podstawy aksjologiczne i intelektualne kształtowania projektu Kodeksu Rodzinnego, [w:] O potrzebie nowego Kodeksu Rodzinnego i jego podstawach aksjologicznych. $W$ 30. rocznice uchwalenia Konwencji o prawach dziecka, red. S. L. Stadniczenko, M. Michalak, Torun 2019, s. 14-15,47-48.

4 Dwudziestowieczna koncepcja dziecka i dzieciństwa nie jest wolna od pewnych wątpliwości czy kontrowersji, zob. T. Smyczyński, Pojęcie dziecka i jego podmiotowość, [w:] Konwencja o prawach dziecka. Analiza i wykładnia, red. T. Smyczyński, Poznań 1999, s. 39-43 oraz P. Jaros, Definicja dziecka, [w:] Konwencja o Prawach Dziecka. Wybór zagadnień (artykuly i komentarze), red. S. L. Stadniczenko, Warszawa 2015, s. 52-62. 
W przeszłości dzieciństwo wprawdzie pojawiało się w rozmaitych klasyfikacjach $^{5}$, ale wyróżnienie tej kategorii miało charakter teoretyczny, formalny i, jak twierdzi część badaczy, nie implikowało dostrzeżenia specyfiki tego okresu i specjalnego podejścia do dziecka. Kwestię sporną stanowi to, kiedy odkryto dziecko i dzieciństwo jako wyjątkowy, wymagający szczególnego traktowania okres w życiu człowieka. Pionierem w przedstawieniu dziecka i dzieciństwa jako tematu badań historycznych był Philippe Ariés. Jego Historia dzieciństwa zapoczątkowała nowy nurt $\mathrm{w}$ badaniach historyków i odegrała istotną rolę $\mathrm{w}$ analizie dzieciństwa z perspektywy socjologicznej, psychologicznej czy pedagogicznej. Według francuskiego mediewisty, przedstawiciela francuskiej szkoły Annales, dzieciństwo nie jest, jak mogłoby się wydawać, naturalnym, przyrodzonym etapem w rozwoju biologicznym człowieka, ale konstrukcją społeczną i kulturową, powstałą nie tak dawno temu ${ }^{6}$.

Ariés dowodzi, że średniowiecze nie wyróżniało ani dzieciństwa, ani wieku młodzieńczego ${ }^{7}$, ponieważ życie rodzinne we współczesnym rozumieniu tego pojęcia, tj. oparte na uczuciach i intymnych relacjach, jest wynalazkiem epok późniejszych ${ }^{8}$. Nie znaczy to, że w średniowieczu dzieci masowo porzucano bądź je zaniedbywano - ludziom średniowiecza brakowało świadomości odrębności dziecka jako jednostki różnej w sposób zasadniczy od człowieka młodego czy dorosłego. Małe dzieci, niezdolne do funkcjonowania w świecie dorosłych, nie liczyły się, nie uwzględniano ich w opisie rodziny, prawdopodobieństwo, że dożyją dorosłości było zbyt małe, by się do nich przywiązywać. Taka postawa wobec dzieciństwa mogła mieć swoje źródło w filozofii Arystotelesa, który postrzegał dzieci jako potencjalnych dorosłych. W ujęciu Stagiryty ostatecznym

5 Periodyzację życia człowieka znaleźć można u Hezjoda, Pindara, Lukrecjusza, Cycerona czy Seneki, a także u autorów średniowiecznych np. Tomasza z Akwinu, Augustyna czy Filipa z Nawarry, który w 1265 r. wydał traktat O czterech okresach życia ludzkiego, zob. D. Żołądź-Strzelczyk, Rozumienie dzieciństwa, [w:] Dziecko w rodzinie i społeczeństwie: Starożytność - średniowiecze, red. J. Jundziłł, D. Żołądź-Strzelczyk, Bydgoszcz 2002, s. 11-17.

6 W. Brzeziński, Obraz dziecka w perspektywie historyczno-porównawczej. Przeszłość we wspótczesności, współczesność w przeszłości, „Przegląd Pedagogiczny” 2012, nr 1, s. 143.

7 Pewnych wskazówek na temat pojęcia dzieciństwa dostarczyć może badanie językowe. W staropolszczyźnie nie znana była dystynkcja miedzy dzieckiem a osobą młodą, wśród etapów ludzkiego życia wymieniano nazwy: „młody”, „mąż” i „stary”, przy czym młodość obejmowała okres od urodzenia do pełnoletniości, różnie definiowanej. I choć później klasyfikacja ta została wzbogacona - np. M. Rej na określenie wieku wyróżnia terminy: „dziecię”, „młodzieniec”, „pan średni”, „starzec”, podobny podział przyjmuje J. Kochanowski, to zarówno w słowniku Reja, jak i Kochanowskiego brakuje abstrakcyjnych pojęć „dzieciństwo” czy „młodość”, zob. D. Żołądź-Strzelczyk, op. cit., s. 20-21.

8 Lawrence Stone, entuzjasta poglądów Ariésa i badacz instytucji rodziny w społeczeństwie angielskim, dowodzi, że nawet pod koniec średniowiecza, w czasie panowania „otwartej wspólnoty rodzinnej” nie istniały bliskie relacje między poszczególnymi członkami rodziny, zwłaszcza między rodzicami a dziećmi, które były wychowywane przez niańki i piastunki, a w dodatku dom rodzinny opuszały wcześnie - często w wieku siedmiu lat, zob. L. Stone, The Family, Sex and Marriage in England 1500-1800, London 1977, passim. 
celem ludzkiego rozwoju jest pełna dorosłość, więc dzieciństwo pełni rolę etapu przejściowego, dziecko jest $\mathrm{z}$ istoty swej formą niedoskonałą i niedokończoną, posiadającą liczne braki. Jego jedyną wartością jest możliwość przeistoczenia się w przyszłości w dorosłego, dziecko samo w sobie w takiej optyce wartościowe nie jest ${ }^{9}$.

Jak dowodzi Ariés, w średniowieczu, a nawet później, w XVI w., powszechnie tolerowane było dzieciobójstwo. Wprawdzie stanowiło ono przestępstwo, ale było praktykowane - często kamuflowano je jako wypadki (dzieci spały wówczas z rodzicami i umierać miały w następstwie „naturalnego” uduszenia). O porzuceniu tej praktyki świadczyć miałby istotny spadek śmiertelności dzieci w XVIII w., spadek, którego nie da się wytłumaczyć wyższym poziomem higieny - rodzicie przestali wówczas pomagać umierać niechcianym dzieciom. Uśmiercanie niechcianych dzieci nie stanowiło wówczas czynu kwalifikowanego jednoznacznie jako moralnie naganny; był to czyn wprawdzie potępiany przez Kościół, ale raczej neutralny moralnie ${ }^{10}$. Powyższy pogląd jest wspierany przez czołowego przedstawiciela psychohistorii Lloyda deMause’a, który opisuje większą część historii ludzkości jako czas brutalnej przemocy wobec dzieci, wykorzystywania ich, czas kiedy rodzice nie mieli skrupułów przed zabijaniem własnych potomków ${ }^{11}$. Dzieje dzieciństwa to „nocny koszmar”, z którego dopiero obecnie ludzkość zaczyna się budzić. Im dalej spogląda się w przeszłość, tym gorzej wygląda sytuacja dzieci - są one zabijane, porzucane, terroryzowane i wykorzystywane seksualnie ${ }^{12}$.

Kolejną przesłanką wspierającą tezę Ariésa o deprecjonowaniu dzieciństwa jest fakt, że sztuka średniowiecza traktowała dziecko bardzo osobliwie - do XII w. dzieciństwo było ignorowane i nie podejmowano prób przedstawiania dzieci, później - w XIII w. - przedstawiano je jako dorosłych w miniaturze; różnica między dorosłymi a dziećmi polegała wyłącznie na wzroście i sile. Analiza sztuki omawianego okresu pozwala uznać średniowiecze - w wymiarze kulturowym i społecznym - za świat pozbawiony dzieci ${ }^{13}$. Zmianę i realistyczne

9 M. Szczepska-Pustkowska, $W$ stronę filozofii dzieciństwa. Adultystyczna wizja dziecka i dzieciństwa $z$ Arystotelesem $w$ tle, „Przegląd Pedagogiczny” 2012, nr 1, s. 24-25.

10 P. Ariés, Historia dzieciństwa, Warszawa 2010, s. 15.

11 D. Żołądź-Strzelczyk, op. cit., s. 9-10.

12 History of Childhood, red. L. deMause, Nowy Jork 1995, s. 1. L. deMause podzielił historię na sześć okresów różniących się podejściem rodziców do dziecka: dzieciobójstwo - od starożytności do IV w. naszej ery, oddawanie czy porzucanie - IV-XIII w., ambiwalencja - XIV-XVII w., „natręctwo", socjalizacja - XVIII w. i wspieranie od połowy XX w. Jednym z przejawów braku umiejętności wczucia się w potrzeby dziecka i zrozumienia go było bicie, które w opinii badacza nie zawsze było wynikiem sadystycznych zapędów rodziców, czasem - paradoksalnie - było przejawem rodzicielskiej miłości. Trwająca całe stulecia gehenna dzieci miała swoje źródło nie w braku miłości, ale w braku refleksji nad wyjątkowością osobowości dziecka, zob. D. Żołądź-Strzelczyk, op. cit., s. 9.

13 P. Ariés, op. cit., s. 12, 57. 
przedstawianie postaci dziecięcych przynosi dopiero XIV w. i sztuka sakralna, w sztuce laickiej ujęte realistycznie postaci dzieci pojawiają się znacznie później, w XV i XVI w., zwykle w towarzystwie dorosłych ${ }^{14}$. Momentem przełomowym w podejściu do dzieciństwa jest pojawienie się w XVI stuleciu portretów dzieci zmarłych - dotychczas na portretach trumiennych przedstawiani byli wyłącznie dorośli. Poza obrazami nagrobnymi osobne portrety dzieci zdarzają się wówczas rzadko, jest ich zdecydowanie więcej w wieku kolejnym, co jest dowodem narodzin nowej wrażliwości i zmiany w podejściu do dzieciństwa. Zmiana ta nie jest pochodną zmian demograficznych; przez pół tysiąclecia - od XIII do XVII w. - warunki demograficzne nie zmieniły się w stopniu znaczącym i śmiertelność dzieci wciąż była bardzo wysoka. Ariés podkreśla, że „odkrycie dziecka” o ponad sto lat wyprzedza znaczącą redukcję stopnia śmiertelności dzieci, związaną $\mathrm{m}$. in. z upowszechnianiem higieny i kontrolą urodzin ${ }^{15}$.

Nie tylko sztuka odbijała charakterystyczną dla średniowiecza obojętność na wyjątkowość dzieciństwa, świadczył o tym także ubiór - dzieci, które zaczynały chodzić ubierano we właściwy dla ich pozycji społecznej strój męski lub żeński, który nie różnił się od strojów dorosłych. Taki stan rzeczy uległ zmianie dopiero w XVII w., kiedy dzieci z domów szlacheckich i mieszczańskich nosiły ubiór stosowny do wieku, a podręczniki etykiety wskazywały wyraźnie, że nie przystoi ubierać się niezgodnie z wiekiem i urodzeniem. Jest to, zdaniem Ariésa, kolejny dowód na rzecz tezy, że to właśnie wówczas - w XVII w. - dzieci zostały wyróżnione jako odrębna społeczność, przy czym znamienne, że starania o wyodrębnienie dziecka dotyczyły jedynie chłopców, jakby dzieciństwo było tylko ich specyficznym stanem ${ }^{16}$.

Teza sformułowana przez francuskiego badacza, popularna i szeroko rozpowszechniona - teza o nieistnieniu w średniowieczu świadomości dzieciństwa jako odrębnego stadium życia i ostatecznym ukształtowaniu tej świadomości dopiero w XVII w. uważana jest dziś przez wielu mediewistów za kontrowersyjną czy wręcz fałszywą ${ }^{17}$, przy czym podważenie ustaleń Ariésa dotyczących istnienia świadomości dzieciństwa w czasach średniowiecza nie pociąga za sobą całkowitego odrzucenia efektów jego pracy badawczej, daje ona bowiem wiele cennych ustaleń dotyczących pozycji dziecka w czasach nowożytnych $^{18}$. Jak wykazał W. Brzeziński, szczególnie zasłużona w budowaniu „pozytywnej" historii dzieciństwa jest mediewistyka angloamerykańska. Jeden

14 Ibidem, s. 62-63.

15 Ibidem, s. 68-70.

16 Ibidem, s. 79-93.

17 Zob. C. Heywood, The History of Childhood, Children and Childhood in the West form Medival to Modern Times, Wiley 2013, passim oraz A. Wilson, The Infancy of the History of Childhood: An Appraisal of Philippe Aries, "History and Theory" 1980, t. 19 (2), s. 132-153.

18 W. Brzeziński, Obraz dziecka..., s. 143. 
z jej przedstawicieli, D. Herlihy, zauważa że postrzeganie dzieciństwa to zjawisko historyczne i siłą rzeczy, wraz z upływem czasu, musi podlegać ewolucji. Jego zdaniem, średniowieczne podejście do dzieciństwa i ówczesny kształt relacji „dzieci-dorośli” jest swoistą wypadkową przekonań i praktyk pochodzących z różnych źródeł - starożytności, świata barbarzyńskiego, wczesnego chrześcijaństwa i nie może mieć charakteru jednolitego. Badacz proponuje, aby stosunek do dziecka w danej epoce historycznej (w tym w średniowieczu) mierzyć wielkością nakładów, jakie dorośli godzą się przeznaczyć na jego wychowanie i utrzymanie. W wyniku przeprowadzonych analiz Herlihy dochodzi do przekonania, że od XII w. ma miejsce stopniowy wzrost nakładów o charakterze społecznym i psychologicznym. Przykładem nakładów pierwszego rodzaju jest zainteresowanie świeckich wychowywaniem i kształceniem dzieci, drugiego - tworzenie przytułków wobec pogarszających się warunków zdrowotnych i zwiększonej śmiertelności wśród dzieci ${ }^{19}$.

Inna amerykańska badaczka - B. Hanawalt - uzasadnia tezę o istnieniu w średniowieczu poczucia odrębności dzieciństwa argumentacją odwołującą się do ludzkiej biologii. Przekonuje, że dzieciństwo jest procesem, gdzie olbrzymią rolę odgrywają ograniczenia natury biologicznej, które nie mogą być zignorowane przez kulturę. Między wymagającym opieki - zwłaszcza w okresie niemowlęctwa - dzieckiem a dorosłym, który mu taką opiekę zapewnia, wytwarza się emocjonalna więź, i miała ona taki sam charakter $\mathrm{w}$ średniowieczu, co w czasach współczesnych. Relacje koronerów z XIV-wiecznej Angliii ${ }^{20}$, którzy opisują sposoby opiekowania się dziećmi, ich codzienne zachowania i zabawy, potwierdzają, że zaspokajane były wówczas nie tylko biologiczne, ale i psychiczne dziecięce potrzeby (przy czym stwierdzenie to jest aktualne zarówno w odniesieniu do dzieci wychowujących się w środowisku wiejskim, jak i tych wzrastających w miastach) ${ }^{21}$.

Obok akt koronerskich innym ciekawym dokumentem dającym wgląd w relację „dziecko - dorosły” w średniowieczu były opisy cudów. Analiza opisów cudów (miracula) pozwala stwierdzić, że poczucie odpowiedzialności za dzieci było udziałem nie tylko rodziców, ale też innych, niespokrewnionych z dzieckiem dorosłych członków danej społeczności. Opisy te przynoszą nową cenną perspektywę w ocenie stosunku dorosłych do dzieci w czasach średniowiecza, dotyczą bowiem przedstawicieli niższych warstw społeczeństwa. Miracula pokazują emocjonalne podejście do dzieci, ból i rozpacz rodziców

19 Idem, „Pozytywna” historia dziecka i dzieciństwa w średniowieczu. Phillipe Ariés a historiografia amerykańska, [w:] Dziecko w rodzinie i społeczeństwie..., s. 263-264.

20 W pracach Hanawalt akta kornerów są po raz pierwszy poddane wnikliwej analizie, wcześniej ze źródeł tych, co może zaskakiwać, nie korzystano, zob. M. Müller, Childhood, Orphans and Underage Heirs in Medieval Rural England: Growing up in the Village, Birmingham 2018, s. 16.

21 W. Brzeziński, „Pozytywna” historia dziecka..., s. 263-264. 
po stracie potomka, które stoją w sprzeczności z zaproponowaną przez Ariésa tezą o obojętności rodziców wobec dzieci i jego tezą o nieistnieniu w średniowieczu świadomości dzieciństwa ${ }^{22}$.

Jednym z błędów zarzucanych Ariésowi jest przyjęcie przezeń postawy szczególnej badawczej optyki, która sprowadza się do oceny średniowiecznej relacji „dzieci - dorośli” za pomocą współczesnej aparatury pojęciowej. Francuski badacz próbował dopatrzyć się w tych relacjach cech, które charakteryzują je dzisiaj, a nie znajdując ich, przyjął że ludzie średniowiecza nie wyróżniali kategorii dzieciństwa. W istocie ustalenia Ariésa dowodzą co najwyżej braku w czasach średniowiecza definicji dzieciństwa pokrewnej definicji współczesnej i braku współczesnych wobec niego postaw, a nie ich braku w ogóle. Możliwe, że istniała wówczas świadomość dzieciństwa alternatywna wobec obecnej i na tyle od niej różna, że dla badaczy dzisiejszych nierozpoznawalna ${ }^{23}$.

J. Schultz w pracy The Knowledge of Childhood in the German Middle Ages opierając się na analizie średniowiecznej niemieckiej twórczości literackiej podejmuje próbę odtworzenia wizji dzieciństwa czasów pełnego średniowiecza (choć zaznacza jednocześnie, że jest to wizja $\mathrm{z}$ konieczności niepełna - autorzy takich tekstów to ludzie wykształceni i pochodzący z wyższych warstw społecznych, a sama ich treść jest określona w pewnym stopniu daną konwencją literacką). Z analizy Schultza wynika, że w średniowiecznych Niemczech istniała świadomość dzieciństwa jako odrębnego okresu w życiu człowieka, przy czym uważano go za czas ułomności, któremu jako takiemu nie należy poświęcać uwagi. Dziecko staje się bohaterem utworu literackiego z uwagi na swoje „dorosłe” zachowanie. Średniowieczna wizja dzieciństwa zakłada także odrębne od współczesnego rozumienie procesów dorastania i wychowania. Na charakter przyszłego dorosłego nie wpływa tutaj suma jego życiowych doświadczeń, dziecka nie można „ukształtować” w procesie wychowawczym; osobowość jest dana człowiekowi w momencie jego narodzin, podobnie jak wszelkie jego uzdolnienia i talenty ${ }^{24}$. Rozwój dziecka polega tu na sukcesywnym przezwyciężaniu ograniczeń i ujawnianiu się jego prawdziwej natury - przy tak rozumianym dzieciństwie zupełnie inaczej niż dziś rysuje się rola dorosłego. Tezę $\mathrm{o}$ istnieniu $\mathrm{w}$ średniowieczu świadomości odrębności dzieciństwa wspiera w obszernej pracy Medieval children brytyjski mediewista, N. Orme, przedstawiając pełną historię dzieciństwa w Anglii od XI do XVI w. Badacz ten, analizując kolejne etapy dorastania dziecka, podkreśla - w wyraźnej opozycji do twierdzeń Ariésa - że dzieciństwo było w średniowieczu uważane za odrębny

22 Ibidem, s. 267-268.

23 Ibidem, s. 271.

24 Ibidem, s. 271-274. 
okres w życiu człowieka; dostrzegano wyjątkowość dziecka i jego różny od dorosłego status ${ }^{25}$.

Ciekawym podsumowaniem dyskusji wokół tez Ariésa jest wydana niedawno praca M. Müller Childhood, Orphans and Underage Heirs in Medieval Rural England: Growing up in the Village. Zasadniczo zgadza się ona z zarzutami stawianymi Ariésowi, za największy „grzech” Francuza uważając użycie we współczesnych badaniach nad istnieniem pojęcia dzieciństwa w średniowieczu nowoczesnych kategorii i pojęć. Jednocześnie jednak Müller podkreśla jego wielkie zasługi - odkrycie nowego przedmiotu badań historycznych ${ }^{26}$ oraz przyjęcie, że samo pojęcie dzieciństwa jest społeczno-kulturową konstrukcją, pochodną określonych historycznych uwarunkowań. Dziś, kiedy znaczna część badaczy uznaje $^{27}$, że średniowiecze miało własną, odmienną od naszej koncepcję dzieciństwa i że dzieci nie były wówczas uważane za małych dorosłych, wyzwaniem jest odkrycie, jaki kształt przybierała ta koncepcja, jak społeczności dorosłych i dzieci w dawnych wiekach oddziaływały na siebie wzajemnie i wreszcie jak same dzieci pojmowały swoje miejsce w ówczesnym społeczeństwie (to ostatnie zadanie określa badaczka jako ekstremalnie trudne - dzieci w średniowieczu nie pisywały wszak listów czy pamiętników $\left.{ }^{28}\right)$. Müller ocenia, że mediewiści współcześni są dziś dopiero na początku drogi prowadzącej do tego celu.

Niezależnie od kontrowersji wokół istnienia poczucia odrębności dzieciństwa w czasach średniowiecza (i uznania czy odmienność oferowanej przez średniowiecze wizji dzieciństwa dzieli od naszego jego rozumienia przepaść której pokonać nie sposób), w XVII w. ukształtowały się dwie całkiem nowe wobec niego postawy. Jedną z nich, przyjętą zwłaszcza w środowisku rodzinnym, jest uczynnienie z dzieci „zabawek” dorosłych. Dziecko jest teraz w centrum świata dorosłych, jest przesadnie rozpieszczane, spełnia się jego zachcianki i we wszystkim się dziecku pobłaża, przy czym postawa ta jest powszechna nie tylko wśród warstw wyższych, ale także wśród ludu. Nastawienie takie wiąże się niewątpliwie z uświadomieniem sobie wyjątkowości i krótkości dzieciństwa ${ }^{29}$.

25 Zob. N. Orme, Medieval children, New Haven and London 2003, passim.

26 Autorka zauważa, że dzieci zaskakująco późno stały się obiektem badań innej dyscypliny - archeologii, zob. M. Müller, Childhood, Orphans and Underage Heirs in Medieval Rural England: Growing up in the Village, Birmingham 2018, s. 9.

27 Ze tym, że wnioski Ariésa były nietrafne zgadza się znaczna część dzisiejszych historyków, specjalistów z zakresu średniowiecza, zarzucających francuskiemu autorowi błędy warsztatowe i skupienie się na zbyt małej liczbie średniowiecznych źródeł. Wśród badaczy innych dyscyplin, np. prawa, filozofii, psychologii czy pedagogiki zainteresowanych analizą pojęcia dzieciństwa, twierdzenia Ariésa są wciąż bardzo popularne i często przywoływane.

28 M. Müller, op. cit., s. 13.

29 P. Ariés, op. cit., s. 190 i nast. 
W omawianym okresie wśród wychowawców i nauczycieli, którzy sprawowali urzędy kościelne i państwowe narodziło się inne nowe nastawienie wobec dziecka, wywodzące się z pełnego zrozumienia jego niewinności i słabości. Nastawienie to, stojące w pewnej opozycji wobec pierwszego, nadało kierunek rozwojowi edukacji aż do XX stulecia. W centrum zainteresowania znalazła się tutaj psychika dziecka i troska o jego wszechstronny rozwój. W regulaminie szkoły Port-Royale zapisano słowa brzmiące zaskakująco współcześnie: „Trzeba doskonale czuwać nad dziećmi, nie zostawiać ich nigdy i nigdzie samych ani $\mathrm{w}$ zdrowiu, ani w chorobie (...). To nieprzerwane pilnowanie dzieci musi być delikatne i niepozbawione pewnego zaufania, żeby czuły, że jesteśmy z nimi dlatego, iż je kochamy, a nie tylko dlatego, żeby ich pilnować... Wtedy raczej polubią to nasze czuwanie, niż będą się go lękać”30. Cytat powyższy pozwala sądzić, że XVII w., początek nowożytności, to nie tylko okres gwałtownych, rewolucyjnych przemian w nauce i filozofii, to także czas, gdy dostrzeżony został fenomen dzieciństwa. Odtąd kwestie związane z dziećmi stają się sprawami godnymi uwagi, dziecko zaczyna się liczyć nie tylko jako przyszły dorosły, ale ważne jest samo w sobie. To dzięki XVII-wiecznym moralistom, którzy wzięli na siebie obowiązek ochrony przyrodzonej niewinności dziecka i wzmocnienia jego naturalnej słabości, dzieciństwo zostało wydłużone poza lata, gdy dziecko mogło być „zabawką” dorosłych. Odkrycie „dziecka” stało się katalizatorem gwałtownych zmian cywilizacyjnych - zdeterminowało przede wszystkim rozwój edukacji.

Ewolucja postawy wobec dziecka w ludzkiej mentalności znajduje swoje najpełniejsze odbicie właśnie w rozwoju edukacji i instytucji szkoły. Szkoły w średniowieczu mieszały uczniów w różnym wieku i były dostępne tylko dla niewielkiej ich liczby, a ich zasadniczym celem było edukowanie, szkoła nie pełniła wówczas funkcji wychowawczych. Szkoły kościelne bardzo długo broniły swojego monopolu na nauczanie, a gdy w końcu zaczęły pojawiać się szkoły prywatne, kanonicy próbowali narzucać im rozmaite ograniczenia dotyczące np. programu nauczania. Znamienne, że wiek uczniów nie był kryterium $\mathrm{w}$ nauczaniu istotnym - dorośli zasiadali $\mathrm{w}$ ławach szkolnym razem z dziesięciolatkami i fakt ten uznawano za zupełnie naturalny (Ariés zauważa, że średniowieczna $\mathrm{z}$ ducha obojętność dla kwestii wieku utrzymała się aż do rewolucji francuskiej). Kolegia tworzyła zazwyczaj grupa uczniów od ośmiu do piętnastu i więcej lat, poddana - co istotne - innemu prawu niż dorośli ${ }^{31}$.

W XVI w. kolegium staje się ważnym elementem życia społecznego; zmienia się system rekrutacji, odtąd kolegia pozostają otwarte także dla synów szlachty, mieszczaństwa, a nawet przedstawicieli warstw niższych. Istotnym elemen-

30 Regulamin Jacqueline Pascal dla szkoły Port-Royal, cyt. za: P. Ariés, op. cit., s. 166-167.

31 P. Ariés, op. cit., s. 197-203. 
tem w ich rozwoju stało się wyróżnienie klas dopasowanych do wieku uczniów (zawsze chłopców), świadczące o rodzącej się świadomości tego, że w obrębie dzieciństwa da się wyróżnić różne kategorie - kolegia zaczęły pełnić wówczas funkcję demograficzną ${ }^{32}$. Choć to moment ważny, szkoła nadal nie miała demograficznej jednorodności, która cechowała ją od końca XIX w. - wciąż ważniejszy niż wiek ucznia był poziom jego zaawansowania w nauce. Tymi, którzy pchnęli rozwój szkolnictwa na nowe tory byli jezuici, oratorianie i janseniści w XVII w. - ci którzy dostrzegli specyfikę psychologii dziecka i szukali metod adekwatnych do dziecięcej psychiki. Jak nikt dotąd docenili moralny i społeczny wymiar systematycznej edukacji w przystosowanych do tego instytucjach (znamienne, że renesansowi humaniści nie przyznawali szczególnej roli dzieciństwu czy młodości; wzorem wczesnych scholastyków popierali oni ideę kształcenia przez całe życie) ${ }^{33}$.

Historię rozwoju szkolnictwa w Anglii prezentuje N. Orme, dowodząc (jak Ariés w odniesieniu do Francji), że przemiany społeczno-kulturalne $\mathrm{w}$ angielskim społeczeństwie pozostawały w ścisłym związku z przemianami w edukacji. Autor przeciwstawia się rozpowszechnionemu przekonaniu o elitarnym charakterze średniowiecznych angielskich szkół - wykazuje (znowu jak Ariés), że nie kształciły one bynajmniej wyłącznie przyszłych duchownych i były otwarte także na przedstawicieli niższych warstw społecznych ${ }^{34}$. Przekonuje, że osiągnięcia średniowiecznej edukacji, w tym te o charakterze organizacyjnym implikowały rozwój społeczeństwa. Badacz przekonuje, że średniowieczne szkoły antycypowały idee i instytucje dzisiejszej edukacji, twierdzi nawet że są tym samym, co szkoły współczesne, tylko w innych historycznych uwarunkowaniach. Orme zaznacza, że pełne zrozumienie osiągnięć średniowiecznego szkolnictwa jest kluczem do zrozumienia natury samego średniowiecza ${ }^{35}$.

$\mathrm{W}$ toku rozwoju systemu edukacji nauczyciele i wychowawcy odkrywają pożytki płynące z utrzymywania w szkole stałej i organicznej dyscypliny. Jest ona pochodną dyscypliny kościelnej i zakonnej, która, przynajmniej w założeniu, przyczyniać się miała do moralnego doskonalenia, a nie być narzędziem

32 Ibidem, s. 203, 206. O wadze pojęcia „szkoła” świadczyć może wyróżnienie poczynione przez słynnego siedemnastowiecznego filozofa, pedagoga i reformatora Jana Amosa Komeńskiego - wyróżnił on siedem faz życia człowieka: narodziny, niemowlęctwo, dziecięctwo, dojrzewanie, młodość, wiek męski i starość. Każdemu z nich przyporządkował Komeński właściwą mu szkołę: pierwsza to szkoła narodzin, czyli „pożyteczne wskazówki dla rodziców na temat pierwszej troskliwej dbałości o rodzaj ludzki już w łonie matki”, druga to „szkoła dziecięctwa na łonie matki czyli o troskliwym wychowywaniu potomstwa ludzkiego od urodzenia do roku życia mniej więcej szóstego", ostatnią klasę tej szkoły stanowić miała klasa pierwszej nauki, a tym samym pierwszej pracy zespołowej, zob. D. Żołądź-Strzelczyk, op. cit., s. 16-17.

33 P. Ariés, op. cit., s. 225.

34 N. Orme, Medieval Schools: From Roman Britain to Renaissance England, New Haven and London 2006, s. 3.

35 Ibidem, s. 337. 
przymusu. Dyscyplina, która miała też nauczać pracy zespołowej i pomagać w sprawowaniu nad dziećmi ustawicznego nadzoru, stała się znamieniem szkoły i statusu ucznia, dzieląc go od wolności dorosłych ${ }^{36}$. Negatywnym aspektem „odkrycia” dzieciństwa stało się stosowanie wobec uczniów kar cielesnych - na baty narażeni byli wszyscy uczniowie, niezależnie od stanu, z jakiego pochodzili $^{37}$ (podczas gdy stosowanie kar cielesnych wobec wysoko urodzonych dorosłych było wyłączone). Dzieci były upokarzane w imię wyższego dobra - kary cielesne miały często na celu ich umoralnianie ${ }^{38}$. Idea, że dzieci nie zasługują na poniżające kary pojawiła się w XVIII w., coraz powszechniej wówczas protestowano przeciwko karze chłosty, zwłaszcza stosowanej wobec dzieci starszych ${ }^{39}$.

Czasy romantyzmu przynoszą jeszcze inną optykę postrzegania dziecka i dzieciństwa. Dziecko, ze swoją unikalną, obcą światu dorosłych wrażliwością, staje się tutaj dla nich wzorem do naśladowania. Dotychczasowy, wielowiekowy tradycyjny porządek uległ teraz załamaniu - dziecko jest dowartościowane i wywyższone ${ }^{40}$. Najpełniej optyka ta widoczna jest w literaturze czasów romantyzmu - dzieci (jak Orcio w Nie-Boskiej komedii Krasińskiego) mają tu często przyrodzony dostęp do ukrytej przed dorosłymi prawdy, obdarzone są zdolnością do jasnowidzenia i zdolnościami profetycznymi ${ }^{41}$. Dziecko posiada też skłonność do zgodnego współistnienia z naturą (jak bohater „Emila” J.J. Rousseau ${ }^{42}$ ), dzieciństwo to stan naturalny, stan przyrodzonej niewinności i wolności, którą człowiek dorosły traci bezpowrotnie, choć do końca życia

36 P. Ariés, op. cit., s. 228-229.

37 Choć większość uczniów stanowiły dzieci mieszczan oraz urzędniczej i duchownej szlachty, w szkołach ówczesnych nie brakowało dzieci rzemieślników i chłopów, z kolei pewna część dzieci szlacheckich w ogóle nie uczęszczała do szkół, zob. P. Ariés, op. cit., s. 229.

38 Ibidem, s. 214-216.

39 Ibidem, s. 216-217. Społeczeństwem, któremu z wielkim trudem przychodzi rezygnacja z wymierzania kar cielesnych są Brytyjczycy. Paul Johnson zauważa, że „Anglicy nigdy nie zapomnieli o tym, by życie swoich dzieci uczynić nieznośnym” i przytacza przykład Earla Shaftesbury’ego, XVII-wiecznego zwolennika reform społecznych i filantropa, który wspomina swoich bezlitosnych, karzących rodziców i prywatną szkołę, gdzie traktowano go równie brutalnie jak w domu, zob. P. Johnson, Historia Anglików, Gdańsk 1995, s. 229. Alex Renton, brytyjski dziennikarz społeczny, autor książki „Jak wytresować lorda” jest przekonany, że „Anglicy słyną w całym cywilizowanym świecie z nienawiści do dzieci" i stwierdza, że w II połowie XX w angielskich elitarnych szkołach z internatem praktyka wymierzania dotkliwych kar cielesnych - w tym chłosty - była normą, przeciw której nie protestowali ani nauczyciele, ani rodzice, zob. https://weekend.gazeta.pl/ weekend/1,152121,26225002,rodzice-wyslali-go-do-szkoly-z-internatem-mowili-wiemy-ze.html, (24.09.2020).

40 W. Brzeziński, Obraz dziecka..., s. 142.

41 Zob. A. Kubale, Dziecko romantyczne. Szkice o literaturze, Wrocław 1984. O wadze mitu dzieciństwa w romantyzmie pisała też Maria Janion, zob. M. Janion, Goraczka romantyczna, Warszawa 1975, passim.

42 Jak zauważa M. Müller, gdy wyobrażamy sobie dziś idyllę wiejskich dzieci żyjących w zgodzie z naturą, kojarzymy ją niemal natychmiast z bohaterem powieści Rousseau, zob. M. Müller, op. cit., s. 2. 
próbuje odnaleźć ${ }^{43}$. Motyw dziecka i dzieciństwa stoi w centrum uwagi twórców romantyzmu - skupiają się w nim najważniejsze idee całej epoki ${ }^{44}$.

Pomocna w rekonstrukcji stosunku dorosłych do dzieci, postawy wobec dzieciństwa w minionych epokach, może być także analiza prawnej sytuacji dziecka - analiza taka pozwala twierdzić, że w wiekach średnich jednak dostrzegano dziecko i dzieciństwo. Średniowieczne prawo kościelne wprowadzało rozgraniczenie między dzieckiem a dorosłym w związku z udziałem w praktykach religijnych, z kolei prawo państwowe wskazywało wiek, w którym dziecko zyskiwało możność rozporządzania swoim majątkiem czy wiek, w którym zdolne było odpowiadać karnie ${ }^{45}$.

W średniowiecznej Polsce w świetle prawa dawało się wyróżnić trzy etapy życia: narodziny i uznanie dziecka przez ojca, dalej lata sprawne i wreszcie lata roztropne. O zdolności do działań prawnych decydował wiek - chłopiec siedmioletni doświadczał ceremonii postrzyżyn, powiązanych z nadaniem imienia, i odtąd przechodził pod opiekę ojca. Moment osiągnięcia lat sprawnych nie był określony dokładnie, dla każdego zainteresowanego ustalano go odrębnie, badając czy osiągnął on dojrzałość fizyczną. Od chwili wejścia w lata sprawne zyskiwał pełną zdolność do działań prawnych, zwłaszcza zawarcia małżeństwa ${ }^{46}$. Do czasu osiągnięcia lat sprawnych władza ojca nad dzieckiem była ogromna - w czasach przedchrześcijańskich przysługiwało mu prawo ius vitae ac necis - mógł on sprzedać dziecko w niewolę (w Polsce prawo to nie utrzymało się tak długo jak w sąsiednich krajach), zastawić, a także zabićn ${ }^{47}$. Później - wraz z wprowadzeniem zasad moralności chrześcijańskiej - zakres władzy ojcowskiej został nieco ograniczony. Pierwszym dokumentem, w którym zawarto normy prawne dotyczące dzieci były Statuty Kazimierza Wielkiego (źródłem owych norm było zarówno prawo zwyczajowe, jak i kanoniczne, władca odwoływał się w ich uzasadnieniu do norm powszechnie uznawanych i twierdzeń powszechnie uważanych za prawdziwe). Statut wiślicki (1347 r.) potwierdzał władzę ojca, zwłaszcza, gdy chodzi o stosunki majątkowe, ale zawierał też przepisy wprowadzające swoistą ochronę dziecka - nie można było go sprzedać ani karać ze szczególnym okrucieństwem, surowo karane było zabicie dziecka, także pochodzącego z nieprawego łoża. Statuty litewskie postanawiały wprost, że dzieci nie mogą być traktowane jako mienie ojca (1529 r.) i wprowadzały karę za ich zabójstwo (1588 r.), przy czym, co znamienne, kara ta była wówczas niższa niż w przypadku zwykłego zabójstwa. O rozwoju praw dziecka w wiekach XVI i XVII świadczą dokumenty dotyczące dzieci osieroconych, np. w jednej z konstytucji

43 A. Kubale, op. cit., s. 18.

44 Ibidem, s. 31.

45 N. Orme Medieval Children, passim.

46 J. Bardach, Historia państwa i prawa Polski, t. 1, Warszawa 1965, s. 75-76.

47 Ibidem, s. 287 
z 1565 r. nakazywano sporządzanie inwentarza majątku dziecka przy jego przejmowaniu przez opiekuna; spis taki był podstawą do rozliczeń po osiągnięciu przez dziecko pełnoletniości ${ }^{48}$. Na początku XVII w. opieka nad osieroconymi dziećmi coraz częściej stawała się sprawą publiczną - np. w Toruniu powołano specjalny urząd sierocy, do którego kompetencji należało zatwierdzanie lub wyznaczanie opiekunów, a także kontrolowanie ich wydatków i rozstrzyganie sporów po upływie czasu opieki. (Szczególnym tego rodzaju dokumentem była Konstytucja 3-go Maja - cztery z zachowanych projektów dotyczą opieki nad dziećmi, zwłaszcza sierotami - postulowano tam ograniczenie władzy opiekuna dziecka i sądową kontrolę jego poczynań) ${ }^{49}$. Chociaż w XVII-wiecznej i XVIII-wiecznej rodzinie ojciec miał jeszcze prawo egzekwowania posłuszeństwa od domowników ${ }^{50}$, zwłaszcza uprawnienie do stosowania kar cielesnych, to podlegało ono coraz liczniejszym ograniczeniom - np. duński kodeks praw z 1683 r. przewidywał, że w sytuacji, gdy ojciec nadwyrężył zdrowie dziecka, może być sądzony jak osoba obca ${ }^{51}$.

Obecnie badania dotyczące pojęcia dzieciństwa zostały częściowo zasymilowane przez nowe, prężnie rozwijające się dyscypliny naukowe. Współcześnie dziecko i dzieciństwo stają się obiektem coraz bardziej zaawansowanych badań, w tym dociekań filozoficznych. Jednym z przedstawicieli tzw. filozofii dzieciństwa jest Gareth B. Matthews, który wśród podstawowych pytań tej nowej dyscypliny wymienia pytanie o genezę i istotę dzieciństwa, sposoby definiowania i rozumienia tego pojęcia. Zadaniem filozofii dzieciństwa jest także badanie postawy dorosłych wobec dzieci i dzieciństwa, a także teorii przyznających dziecku rozmaite miejsca w społeczeństwie. Na gruncie omawianego działu filozofii pojawiają się rozważania dotyczące historii dzieciństwa i podmiotowości dziecka, przyznawanych im praw, a także porównawcze studia dzieciństwa w rozmaitych kulturach ${ }^{52}$. W obszar swoich zainteresowań filozofowie dzieciństwa włączają również teorie z zakresu kognitywnego i moralnego rozwoju dziecka, bazujące na najnowszych odkryciach medycyny i psychologii. Wśród prowadzonych przez nich badań na szczególną uwagę zasługują te dotyczące

48 D. Żołądź-Strzelczyk, op. cit., s. 18 i nast. W Anglii już w średniowieczu wypracowano podobne rozwiązania - władze średniowiecznego Londynu przyjęły przepisy pozwalające na ochronę praw dzieci osieroconych do ich majątków i ochronę terminujących u mistrzów cechowych przed nadużyciami, zob. W. Brzeziński, „Pozytywna” historia dziecka..., s. 267, zob. też M. Müller, op. cit., s. 13-21.

49 D. Żołądź-Strzelczyk, op. cit., s. 18 i nast.

50 W osiemnastowiecznej polskiej rodzinie szlacheckiej władza ojca nad dziećmi wciąż była bardzo rozległa - więź między nimi oparta była na szacunku i strachu, u wrażliwych dzieci strach przed ojcowskim gniewem i karą często prowadził do stanów chorobowych, zob. K. Wróbel-Lipowa, Relacje dzieci-rodzice $w$ polskiej rodzinie ziemiańskiej $w$ XVIII wieku, [w:] Dziecko $w$ rodzinie i społeczeństwie..., s. 105.

51 T. Munck, Europa XVII w. 1598-1700, Warszawa 1998, s. 121.

52 M. Szczepska-Pustkowska, op. cit., s. 36. 
zachowań niemowląt, wykazujących - jak się okazuje - zaskakujące umiejętności w zakresie kooperacji i komunikacji, pozwalające im radzić sobie w nowej i nieznanej rzeczywistości.

Badanie zarówno dzieciństwa, jak i podmiotowości dziecka zyskuje współcześnie wymiar interdyscyplinarny, co wyznaczy kierunek rozwoju tych badań w przyszłości. Przedstawiona powyżej ewolucja pojęcia dzieciństwa oraz kontrowersje związane $\mathrm{z}$ jego istnieniem $\mathrm{w}$ czasach średniowiecza pozwalają stwierdzić, że nie jest ono kategorią ahistoryczną i uniwersalną, aktualną w każdym czasie. Analiza dzieciństwa i zakresu podmiotowości dziecka w danym stuleciu musi uwzględniać każdorazowo realia epoki, w tym osiągnięcia nauki - szeroki kontekst społeczno-kulturowy. Badanie takie powinno ponadto odwoływać się do kategorii pojęciowych właściwych określonym czasom oraz uwzględniać aspekty językowe.

\section{Bibliografia}

Anderson M., Approaches to the history of the western family, 1500-1914, Cambridge 1995.

Ariés P., Historia dzieciństwa, Warszawa 2010.

Bardach J., Historia państwa i prawa Polski, t. 1, Warszawa 1965.

Brzeziński W., „Pozytywna” historia dziecka i dzieciństwa w średniowieczu. Phillipe Ariés a historiografia amerykańska, [w:] Dziecko $w$ rodzinie i spoleczeństwie. Starożytność - średniowiecze, red. J. Jundziłł, D. Żołądź-Strzelczyk, Bydgoszcz 2002.

Brzeziński W., Obraz dziecka w perspektywie historyczno-porównawczej. Przeszłość we współczesności, współczesność w przeszłości, „Przegląd Pedagogiczny” 2012, $\mathrm{nr} 1$.

Golus A., Od przedmiotu do podmiotu. Status dziecka w rodzinie i społeczeństwie, „Studia Edukacyjne" 2018, nr 48.

Heywood C., The History of Childhood, Children and Childhood in the West form Medival to Modern Times, Wiley 2013.

History of Childhood, red. L. deMause, Nowy Jork 1995.

Jacyno M., Szulżycka A., Dzieciństwo. Doświadczenie bez świata, Warszawa 1999.

Janion M., Goraczka romantyczna, Warszawa 1975.

Jaros P., Definicja dziecka, [w:] Konwencja o Prawach Dziecka. Wybór zagadnień (artykuty i komentarze), red. S. L. Stadniczenko, Warszawa 2015.

Johnson P., Historia Anglików, Gdańsk 1995.

Konwencja o Prawach Dziecka. Wybór zagadnień (artykuly i komentarze), red. S. L. Stadniczenko, Warszawa 2015.

Kubale A., Dziecko romantyczne. Szkice o literaturze, Wrocław 1984. 
Müller M., Childhood, Orphans and Underage Heirs in Medieval Rural England: Growing up in the Village, Birmingham 2018.

Munck T., Europa XVII w. 1598-1700, Warszawa 1998.

Orme N., Medieval children, New Haven and London, 2003.

Orme N., Medieval Schools: From Roman Britain to Renaissance England, New Haven and London 2006.

Smolińska-Theiss B., Dzieciństwo, [w:] Encyklopedia pedagogiczna XXI wieku, red. T. Pilch, Warszawa 2003.

Smyczyński T., Pojęcie dziecka i jego podmiotowość, [w:] Konwencja o prawach dziecka. Analiza i wykładnia, red. T. Smyczyński, Poznań 1999.

Stadniczenko S. L., Podstawy aksjologiczne i intelektualne kształtowania projektu Kodeksu rodzinnego, [w:] O potrzebie nowego Kodeksu rodzinnego i jego podstawach aksjologicznych. W 30. rocznicę uchwalenia Konwencji o prawach dziecka, red. S. L. Stadniczenko, M. Michalak, Toruń 2019.

Stone L., The Family, Sex and Marriage in England 1500-1800, London 1977.

Szczepska-Pustkowska M., W stronę filozofii dzieciństwa. Adultystyczna wizja dziecka i dzieciństwa z Arystotelesem w tle, „Przegląd Pedagogiczny” 2012, nr 1.

Wilson A., The Infancy of the History of Childhood: An Appraisal of Philippe Ariés, „History and Theory” 1980, t. 19 (2).

Wróbel-Lipowa K., Relacje dzieci-rodzice w polskiej rodzinie ziemiańskiej w XVIII wieku, [w:] Dziecko w rodzinie i społeczeństwie. Dzieje nowożytne, red. K. Jakubiak, W. Jamrożek, Bydgoszcz 2002.

Wywiad E. Jankowskiej z A. Rentonem, „Gazeta Wyborcza” na: https://weekend.gazeta. pl/weekend/1,152121,26225002,rodzice-wyslali-go-do-szkoly-z-internatemmowili-wiemy-ze.html

Żołądź-Strzelczyk D., Rozumienie dzieciństwa, [w:] Dziecko $w$ rodzinie $i$ społeczeństwie: Starożytność - średniowiecze, red. J. Jundziłł, D. Żołądź-Strzelczyk, Bydgoszcz 2002. 


\section{STRESZCZENIE}

\section{Spory o pojęcie dzieciństwa i podmiotowość dziecka od średniowiecza do czasów nowożytnych}

W artykule przedstawiono ewolucję rozumienia dzieciństwa i związanego z nim pojęcia podmiotowości dziecka. Celem publikacji jest wykazanie, że pojęcie dzieciństwa - wieloznaczne i będące współcześnie przedmiotem analiz badaczy różnych gałęzi nauki - ma kontrowersyjną historię. Dyskusyjne jest istnienie koncepcji dzieciństwa w średniowieczu; jeśli istniała ona wówczas - jak zakłada znaczna część dzisiejszych historyków mediewistów - to była zupełnie różna od dzisiejszej, ufundowanej na XX-wiecznych pojęciach i analizie współczesnych relacji między dorosłymi a dziećmi. Pytanie o kształt tej koncepcji jest wciąż otwarte - istotne, że nie powinna być oceniana na podstawie realiów XXI w. Czasem, w którym narodziła się świadomość dzieciństwa pokrewna dzisiejszej, związana z zauważeniem i podkreśleniem wyjątkowej konstrukcji psychicznej dziecka było XVII stulecie - działali wówczas wybitni pedagodzy-reformatorzy, dzięki którym zaszły istotne zmiany w ówczesnym systemie edukacji. Spory wokół pojęcia dzieciństwa uświadamiają, jak trudno pojęcie to zdefiniować - definicja ta jest dla każdej z epok odrębna i jest swoistą pochodną realiów społeczno-kulturowych. Dzieciństwo powinno być traktowane jako fakt historyczny; każda epoka historyczna może przyjmować własną jego koncepcję.

\section{SUMMARY}

\section{Disputes about the concept of childhood and the child's subjectivity from the Middle Ages to the early modern times}

The article presents the evolution of the understanding of childhood and the related notion of child's subjectivity. The aim of the article is to show that the concept of childhood - ambiguous and currently being analyzed by researchers from various branches of science - has a controversial history. The existence of the concept of childhood in the Middle Ages is debatable; if it existed at that time - as a significant part of contemporary medieval historians assume - it was completely different from today's, founded on the 20th century concepts and analysis of contemporary relations between adults and children. The question about the shape of this concept is still open - it is important that it should not be assessed on the basis of the realities of the 21st century. The seventeenth century was the time when the awareness of childhood similar to the present day, related to noticing and emphasizing the unique psychological structure of a child, was born. At that time appeared outstanding educators-reformers, thanks to whom significant changes took place in the education system of that time. Disputes around the concept of childhood make us realize how difficult it is to define it - this definition is separate for each epoch and is a specific derivative of socio-cultural realities. Childhood should be regarded as a historical fact; each historical epoch can adopt its own conception. 